\title{
THE ROLE OF FOREST ECOSYSTEMS IN THE PROCESS OF MITIGATION AND ADAPTATION TO THE EFFECTS OF CLIMATE CHANGE\#
}

\author{
Ratko Ristić*, Ivan Malušević, Boris Radić, Slobodan Milanović, Vukašin Milčanović, \\ Siniša Polovina
}

\author{
${ }^{1}$ Forestry Faculty, University of Belgrade, Serbia \\ *e-mail: ratko.ristic@sfb.bg.ac.rs
}

\begin{abstract}
Forest ecosystems provide a wide range of environmental services with an important role in the Earth's lifesupport system. Climate change in Southeastern Europe (SEE) and forecasts for the period until 2070 have a huge impact on the present and future planning in forestry and watershed management, due to the observed trends: the increment of mean annual air temperature from $2,5-5,0^{\circ} \mathrm{C}$ until the end of the XXI century; redistribution of annual precipitation, with much more precipitation in the spring-summer period, during short, intensive rain events; a decrease of annual precipitation and soil moisture of 10-20\%, with extreme consequences: dieback and disappearance of forests in huge areas of hilly-mountainous regions. Degradation and loss of forests leads to spread and intensification of soil erosion, with frequent torrential floods, mudflows, landslides, and avalanches. Stable forest ecosystems are pillars of sustainable development, repopulation and could provide means and resources to battle and overcome poverty in mountainous regions of southeast Europe.
\end{abstract}

Key words: forest ecosystems; climate change; flood prevention; erosion control; planning

\section{INTRODUCTION}

Forest ecosystems are the most complex land ecosystems whose functions are public goods [1]: protection against natural hazards (soil erosion and desertification, mudflows, torrential floods, landslides, avalanches); preservation of biological diversity; water supply; recreation; carbon-dioxide fixation; spiritual and aesthetic values; education. At the same time, they provide raw materials for the wood processing industry.

According to the Serbian National Forest Inventory [2], forests in Serbia cover 2.252.400 ha (29.1\% of the total area of the country). Forests cover approximately $40 \%$ of the SE European countries while the EU average is $42 \%$ [3]. The average volume in state-owned forests is $184 \mathrm{~m}^{3} / \mathrm{ha}$, and the annual volume increment amounts to 4.5 $\mathrm{m}^{3} /$ ha $(2.4 \%)$. The average volume in privatelyowned forests is $133 \mathrm{~m}^{3} / \mathrm{ha}$ and the annual volume increment is $3.5 \mathrm{~m}^{3} / \mathrm{ha}(2.6 \%)$. Private forests cover some $1.058 .400 \mathrm{ha}$, or approximately $47 \%$ of Serbia's total forest area [2]. There are about 500.000 private forest owners, who on average each possess about 2 ha of forests, often divided into six or seven parcels, which are often not spatially connected. Due to the small size and low productivity, most private forest owners cannot afford to pay for professional forest management.

Protective, productive and social functions of forest ecosystems have to be harmonized through the concept of Sustainable Utilization, which means: "...to meet the needs of the present without compromising the ability of future generations to meet their own needs by practicing a land stewardship ethics which integrates the reforestation, managing, growing, nurturing and harvesting of trees for useful products with the conservation of soil, air and water quality, wildlife and fish habitat, and aesthetics" [4]. 


\section{DOMINANT FACTORS THREATENING FOREST ECOSYSTEMS}

\section{Climate change}

The observed climate data in the period since 1961 until the present, shows considerable changes in temperature and precipitation. Most affected by the temperature increase are central parts of Serbia. The hottest year in Serbia was 2014, and additionally, out of the 10 hottest years on record, 9 happened since the year 2000 [5]. The average temperature increase on the territory of Serbia was $1.2{ }^{\circ} \mathrm{C}$ for the period 1996-2015, with the highest increase of maximum daily temperature during the summer season, $2.2{ }^{\circ} \mathrm{C}$ [6]. At the same time, mean annual precipitation decreased during the summer period $(-9.2 \%)$. The frequency and duration of heat waves showed a sudden increase after 1982 [7]. The flow of warm and dry air from North Africa has caused severe heat waves in Serbia, with an absolute maximum temperature in $2007\left(44.9^{\circ} \mathrm{C}\right)$. During the summer of 2012, the worst drought since the beginning of measurement was recorded at several stations in Serbia [7].

The IPCC (International Panel on Climate Changes) created scenarios A1B and A2, known as 'medium' and 'high' forcing scenarios: scenario A1B considers a future world of strong economic growth, declining world population, rapid introduction of new and more efficient technologies, and balanced use of all energy sources, with atmospheric $\mathrm{CO}_{2}$ concentration close to $690 \mathrm{ppm}$; the A2 scenario describes a very heterogeneous world, with continuously increasing global population and economic growth and technological change more fragmented and slower than in scenario A1B. Considered atmospheric $\mathrm{CO}_{2}$ concentration at the end of the $21^{\text {st }}$ century is up to $850 \mathrm{ppm}$ (between 1.8 and 2.2 times higher than the present value of $\sim 390 \mathrm{ppm}$ ) [8]. By the end of the $21^{\text {st }}$ century, according to scenario $\mathrm{A} 1 \mathrm{~B}$, an overall increase of about $2.5-5{ }^{\circ} \mathrm{C}$ is expected over Serbia for surface air temperature [5]. The largest warming and decrease of precipitation is projected for summer periods [9]. The most extreme prediction, based on scenario A2, is for the period 2071-2100, with summer temperatures increasing by about $7^{\circ} \mathrm{C}$ in the Balkan countries (including Serbia), while changes for the rest of the region will be within the range of $3-4{ }^{\circ} \mathrm{C}[10]$. The number of days with an absolute maximum temperature $>30{ }^{\circ} \mathrm{C}$ (tropical days) is expected to increase (especially in northern parts of Serbia), while the total number of days with an absolute minimum temperature $<0{ }^{\circ} \mathrm{C}$ (frost days) will decrease [11]. The vegetation period will start earlier, and end later, as is already registered to be happening in the Northern Hemisphere [12].
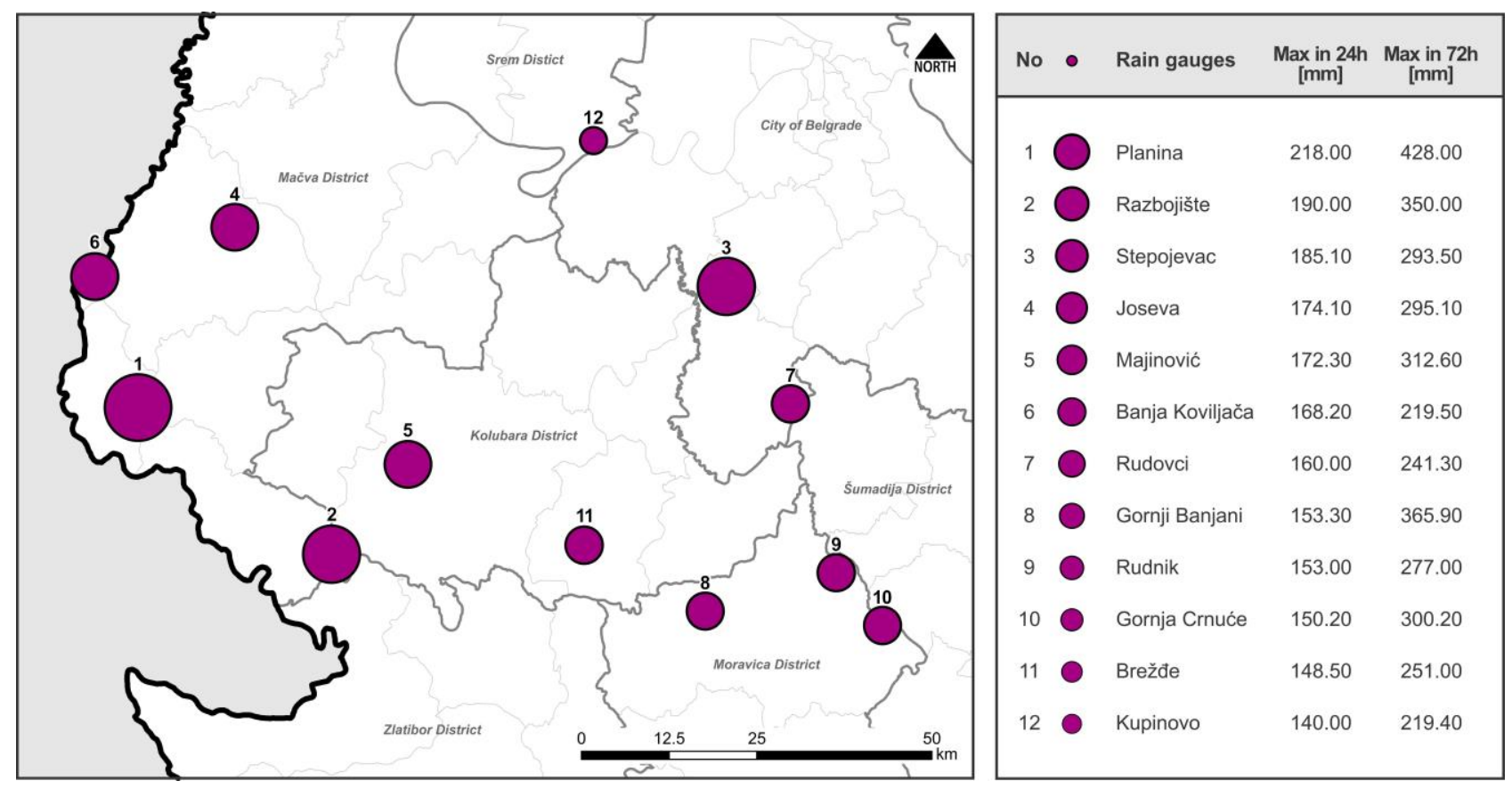

Figure 1. Spatial disposition of the recorded precipitation for $24 \mathrm{~h}$ and $72 \mathrm{~h}$ at rain-gauge stations in West and Central Serbia, during catastrophic torrential floods in May 2014 
Scenario A1B shows a precipitation deficit between $9-18 \%$, except an increase in spring in northern Serbia. According to scenario A2, precipitation will decrease by as much as $16.4 \%$ in spring in south Serbia and increase by $9.6 \%$ in winter in northern Serbia [11]. According to scenario A2, an increase of number of days with heavy precipitation (precipitation $\geq 10 \mathrm{~mm}$ ) is expected. In south Serbia an increase of about $20 \%$ is expected during winter, and in the north, an increase of heavy precipitation days is expected for all seasons. According to scenario A1B, there will be an increase of heavy precipitation days during spring and winter in the north, while at other seasons, and in the south, there be a decrease of less than $15 \%$ [11]. In both scenarios, the duration of the dry period (maximum number of consecutive days with daily precipitation $<1 \mathrm{~mm}$ ) is expected to be extended. For the period of 2079-2100, the reduction of rainfall in the Balkan region might be considerably large, i.e. about $20 \%$ of the mean precipitation found during the period 1961-1990 [13].

The paradigm for altered climate conditions was the giant cyclone formed over the Balkans in May 2014, with the following characteristics: immobility, duration of about 7 days and huge spatial coverage of more than $50.000 \mathrm{~km}^{2}$ [14]. The cyclone produced intense precipitation which was the dominant input for fast surface runoff generation and torrential flood forming, with recurrence intervals from once in 1.000 years to once in 5.000 years [14]. During this event, historical records for $24 \mathrm{~h}$ and $72 \mathrm{~h}$ at rain gauge stations were overcome at most measuring points in West and Central Serbia (Figure 1).

\section{Forest fires}

Fires are a significant factor of deforestation in Serbia. In 2007 alone, 258 forest fires were registered on an area of 33,000 hectares (of which 16.000 hectares were forests), which caused damage of about 40 million $€$, with the reclamation cost of 24 million $€$ [15]. During the summer of 2007, heat waves registered in the Balkan region including Serbia, were responsible for the largest firedamaged area. There was an increased frequency of forest fires (2002, 2007, 2012 and 2017), that corresponds to the appearance of heat waves and drought periods. In the period 2012-2016, in forests managed by the Public Enterprise "Serbian Forests", 316 fires were recorded, on a total area of 8.074,55 hectares [15]. In 15 cases the cause was thunder, in 158 the fires were man-induced and in 143 cases the causes were unknown (likely man-induced).

\section{Forest dieback}

The extreme drought recorded in 2012 damaged sensitive relationships between spruce and root pathogens (Heterobasidin parviporum), after which there was a collapse of the trees and weakening of their resistance [16]. On damaged and physiologically weakened trees, populations of Ips typographus and Pityogenes chalcographus have increased manifold [16]. In the following years, these two species also colonized completely healthy trees, which led to extensive spruce dieback in the Golija region. The extension of the vegetation period caused an increase in the number of generations of bark beetles which added to the intensity of damage in the Park of Nature "Golija" (PNG) [16]. The total volume of spruce trees logged because of the dieback (2012-2016) in PNG amounted to $67,434 \mathrm{~m}^{3}$ [16]. Increases in average annual temperatures and longer periods of drought lead to more frequent outbreaks of defoliators that cause great damage to temperate broad-leaf forests. In 2013, Gypsy moth (Lymantria dispar dispar) caterpillars defoliated 60,000 hectares of oak and beech forests in Serbia [17].

\section{Forest fragmentation}

Fragmentation of forests is initiated when forest roads, electric power and water-supply installations, ski trails and ski lift corridors, penetrate into old growth or mature forest, dividing large surfaces into small elements, changing their habitat conditions [18]. Fragmentation is followed by habitat loss that seriously endangers forest wildlife. The changes of forest microclimate are noticeable at a distance of up to $60 \mathrm{~m}$ from fragment edges [19].

Altered radiation, wind, water, and nutrient regimes create new habitat conditions, inducing tree mortality in fragments and strongly influence forest dynamics and structure. An illustrative example of forest fragmentation is the destruction of 26 ha of native mature forest in the ski resort "Stara Planina" [20], when two fragments were created (Figure 2), endangering two local endemic plant species Campanula calycialata (found only in the proximity of), and Senecio pancici (steno endemic of the Central Balkans). After the development of the ski resort, the buzzard (Buteo rufinus) disappeared from the area (IUCN Red list of threatened species, 2006), and populations of skylark (Alauda arvensis, IUCN Red list of threatened species, 2008) and Eurasian Woodcock (Scolopax rusticola, IUCN Red list of threatened species, 2008) have been significantly reduced [21, 22]. 


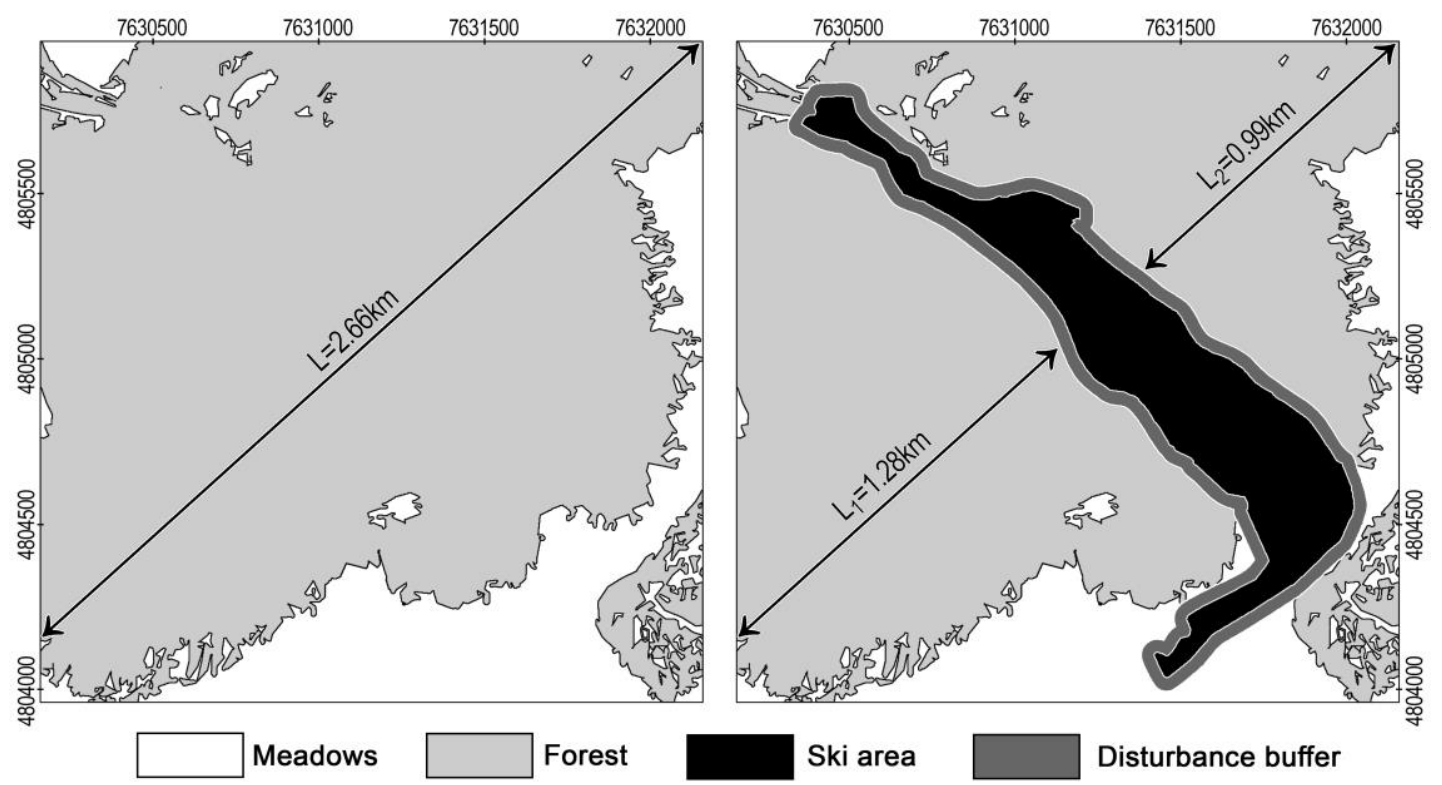

Figure 2. Forest fragmentation at the "Stara Planina" ski resort [18]

\section{Illegal logging}

According to the EU definition, "illegal logging and related trade occur when timber is harvested, transported, processed, bought or sold in violation of national or sub-national laws" [3]. Illegal logging in Serbia is strongly linked to numerous factors including unfavourable social and economic conditions; low awareness for the importance of forest protection; institutional inefficiencies, weak law enforcement; inefficient judicial and sanctioning systems [23]. Two types of illegal logging can be clearly distinguished in the Western Balkans: poverty-driven illegal logging and commercial illegal logging. Illegal logging carried out to fulfil the needs of poor local populations is negligible compared to the overall enterprise of illegal logging [23].

The estimated volumes of illegally cut wood in Serbian public forests are between 10.000 and $32.000 \mathrm{~m}^{3}$ per year, while the total amount of illegally cut wood in private forests is estimated at about $500.000 \mathrm{~m}^{3}$ [24]. Illegal logging is also very pronounced in southern Serbian municipalities (Vranje, Kuršumlija, Leskovac, Raška and Leposavić), near Kosovo and Metohija [25]. The total quantity of registered illegal logging in this part of Serbia is more than $200.000 \mathrm{~m}^{3}$ for the period 2002 to 2008 [3].

\section{Small hydro-power plants}

In accordance with the National Renewable Energy Action Plan of the Republic of Serbia (http://www.mre.gov.rs/doc/efikasnost-izvori) around 90 Small Hydro-power Plants (SHPP) have been built in Serbia, of Derivation Type (SHPP-DT), with pipelines in length of $2-5 \mathrm{~km}$. Additionally, 856 SHPP-DTs are planned for construction [26] in mountainous regions of Serbia, mainly in protected natural areas (National Parks, Nature Parks, Special Nature Reserves). Serbia is the least auspicious country in the Balkans when it comes to indigenous surface waters (annual specific runoff $\mathrm{q}=5,7 \mathrm{l} \mathrm{s}^{-1} \mathrm{~km}^{-2}$ ) [27], which is why mass construction of SHPPs began on rivers considered to be hydrologically, but also ecologically most valuable. The implementation of this has led to the endangerment or even disappearance of endemic and protected fish species, fragmentation of the most valuable aquatic habitats, fragmentation of forests (due to the construction of access roads and derivative pipelines), endangered water supply of local communities and intensive erosion along access roads [28].

The problems identified as a result of construction of the existing SHPPs require urgent review of procedures for issuing licenses for both planned and already constructed facilities, with the imperative of prohibiting further construction in protected areas. All the planned SHPPs would provide only $2-3.5 \%$ of the annual energy needs of Serbia, but that would mean total devastation of most of the quality watercourses in the mountain regions of Serbia [29].

For example, due to the small energy contribution and detrimental environmental consequences, the authorities in the US have removed more than 1,000 (SHPP-DT), in the period 1993-2017 [30]. Similar processes are taking place in France, Spain, 
Germany, and Sweden. Other ways of producing energy from renewable sources have far less negative effects on the environment, and if the current losses of the Public Enterprise "Electric Power Industry of Serbia" during the transmission of electricity, were reduced by only $2 \%$ that would eliminate the need for derivative SHPP [29].

According to the Study of European organizations dealing with the protection of watercourses [31], eight SHPPs built in Albania, Croatia, and Macedonia in the period 2013-2015, were financed by the European Bank for Reconstruction and Development (EBRD) and the European Investment Bank (EIB). Drastic examples of violations of national legislation and environmental standards have been noticed, so the EBRD and the EIB reviewed its business policy for the year 2018, in terms of financing the construction of MHE [32]. Nevertheless, the construction of as many as 2.800 objects [33] has been planned in the Balkans, although this region is already one of the most endangered by current climate anomalies, which, among other things, leads to significantly reduced flow rates in low flow periods.

\section{TORRENTIAL FLOODS, EROSION PROCESSES, AND FOREST ECOSYSTEMS}

Torrential floods are the most frequent natural catastrophic events in the SEE region, causing loss of human lives and huge material damage, in both urban and rural areas [34]. In Serbia alone, torrential floods have caused death of more than 130 people in the last 64 years and material damage estimated at more than 10 billion $€$ [34]. Representative examples are torrential floods that occurred in Serbia in May and September 2014 (more than 50 people died, direct material damage of over 2 billion dollars), in Bosnia and Herzegovina in May 2014 (27 people died) and in Macedonia in August 2016 (21 people died). The frequency of these events, their intensity and diffusion throughout the country make them a permanent threat with severe consequences to environmental, economic and social spheres [35]. The climate, along with the specific characteristics of the relief, distinctions of the soil and vegetation cover, severe erosion processes result in the frequent occurrence of torrential floods. Torrential (flash) flood represents a sudden appearance of maximal discharge in a torrent bed with a high concentration of sediment. In extreme cases, the two-phase fluid flows out from the torrent bed with enormous destructive energy. The two-phase fluid (water and sediment) can contain fractions (60\% of total volume) with different granulations ranging from clay particles to rock fragments, with diameters of up to $5.0 \mathrm{~m}$ and a total mass of over 200 tons [36].

The soil and vegetation cover directly affect the intensity of the surface runoff by creating "losses" of precipitation through the processes of interception, evaporation, transpiration, and infiltration $[37,38]$. The eroded soil becomes compacted with an insufficient amount of nutrients and organic matter. The infiltration rates and water-storage capacity of the soil profile are reduced, which, in turn, increases the overland flow and erosion. The amount of surface runoff depends on the total precipitation, the type of land use, and the characteristics of the vegetation cover as well as on the air and water capacity of the soil $[39,40]$. Clearcutting and the removal of forest vegetation influence the water balance by affecting evapotranspiration and possibly snow accumulation and melting. These activities increase the peak discharge by as much as $50 \%$ in small basins and $100 \%$ in large basins [41]. Timber harvesting has the potential to increase the total flow and lengthen the duration of larger flows while enabling sediment movement [42]. The risk of erosion processes, fast surface runoff, and torrential floods can be significantly decreased by land-use changes (afforestation of bare land, reclamation of degraded forests, meadows and pastures, siltfiltering strips, contour farming, and terracing) in order to reduce erosive material production and meliorate water infiltration and water storage capacity of the soil.

\section{CONCLUDING REMARKS}

Climate change and natural hazards cannot be prevented, but a better understanding of the processes and scientific methodologies for their prediction can help mitigate their impacts. Very often, the human factor contributes significantly to the effects of climate change and a range of disasters, with activities such as deforestation, mismanagement of forest and agricultural surfaces, man-induced forest fires, uncontrolled urbanization and the lack of erosion control and flood protection structures.

The observed data processing and model-based climate projections show that until the end of XXI century, climate warming in Serbia and SEE will cause an increase in the mean temperature of 2.5-5.0 ${ }^{\circ} \mathrm{C}$, with a reduction of summer precipitation, an increased frequency of heavy precipitation, and significantly less snow precipitation, while the total annual values do not show significant changes [11].

The impacts of climate change associated with negative anthropogenic influence lead to the degradation of forests and huge soil surfaces which endanger biodiversity, economic activities, and 
health conditions in SEE countries. The derived results should raise public awareness and point to imperative action to apply mitigation and adaptation measures in the fields of water resources management, forestry, agriculture, nature protection, and biodiversity preservation. Wood processing industry practices and products must be raised in order to achieve higher ratio of final products when compared to raw wood, maximizing financial benefits and decreasing the volume of exports of semi-final products, which would provide a more rational utilization of the growing stock.

Forest management from the aspects of mitigation of climate change effects and natural hazards prevention should be complementary with other demands such as environmental protection, sustainable soil usage, drinking water supply, local economic development and sustained biodiversity. The restoration of eroded and deforested watersheds is one of the key activities in the process of mitigation and adaptation to the effects of climate change, as well as the reduction of disaster risk. It involves biotechnical works on slopes and technical works in the channel network, coordinated within a precisely defined administrative and spatial framework. Cooperation and overcoming of conflicts between the sectors of water resources management, forestry, agriculture, energetic, environmental protection and local economic development are indispensable at the following levels: policy, spatial planning, practice, investments and education. It is very important to connect these measures with the process of mitigation and adaptation to climate change in accordance with the platforms of UNFCC (United Nation Framework Convention on Climate Change) and UNCCD (United Nation Convention on Combat Desertification), inform and educate all stakeholders about the planned activities and provide subsidies for their implementation and media support.

Acknowledgments. This study was supported by the Ministry of Education and Science of the Republic of Serbia within project 43007 ("Studying climate change and its influence on the environment: impacts, adaptation, and mitigation-subproject: Frequency of torrential floods and degradation of soil and water as a consequence of global changes").

\section{REFERENCES}

[1] ECC, A new EU Forest Strategy: for forests and the forest-based sector, 2013. (https://eurlex.europa.eu/ legal-content/EL/TXT/PDF/?uri=CELEX: 52013DC0 $659 \mathrm{R}(01))$

[2] Ministry of Agriculture, Forestry and Water Management of the Republic of Serbia - Forest
Directorate (MAFWM-FD), The National Forest Inventory of the Republic of Serbia, The growing stock of the Republic of Serbia, Belgrade, 2009.

[3] M. Markus-Johansson, B. Mesquita, A. Nemeth, M. Dimovski, C. Monnier, P. Kiss-Parciu, Illegal Logging in South Eastern Europe Regional Report, REC Working Paper, The Regional Environmental Center for Central and Eastern Europe (REC), Szentendre, Hungary, 2010.

[4] American Forest \& Paper Association, Progress Report on the American Forest \& Paper Association's Sustainable Forestry Initiative, Washington DC., 1997.

[5] A. Vuković, M. Vujadinović, S. Rendulić, V. Đurđević, M. Ruml, V. Babić, D. Popović, Global warming impact on climate change in Serbia for the period 1961-2100, Thermal Science, 22, 6 (2018), pp. 2267-2280.

[6] M. Ruml, E. Gregorić, A. Vujadinović, S. Radovanović, G. Matović, A. Vuković, A. Počuča, Đ.Stojičić, Observed changes of temperature extremes in Serbia over the period 1961-2010, Atmospheric Research, 183 (2016), pp. 26-41.

[7] M. Unkašević, I. Tošić, Seasonal analysis of cold and heat waves in Serbia during the period 19492012, Theoretical and Applied Climatology, 120 Iss.1-2 (2014), pp. 29-40.

[8] N. Nakićenović, R. Swart, Special report of the Intergovernmental Panel on Climate Change, Cambridge University Press, Cambridge, 2000.

[9] A. Kržić, I. Tošić, B. Rajković, V. Đurđrević, Some Indicators of the Present and Future Climate of Serbia According to the SRES-A1B scenario (in: A. Berger et al. (eds.), Climate Change, SpringerVerlag, Wien 2012).

[10] B. Önol, F. Semazzi, Regionalization of climate change simulations over the eastern Mediterranean, Journal of Climate, 22, 8 (2009), pp. 1944-1961.

[11] A. Kržić, I. Tošić, V. Đurđević, K. Veljović, B. Rajković, Changes in climate indices for Serbia according to the SRES-A1B and SRES-A2 scenarios, Climate Research, 49 (2011), pp.73-86.

[12] P. Frich, L. V. Alexander, P. Della-Marta, B. Gleason, M. Haylock, T. Peterson, Observed coherent changes in climatic extremes during the second half of the twentieth century, Climate Research, 19, (2002) pp. 193-212.

[13] S. Gualdi, B. Rajkovic, V. Djurdjevic, S. Castellari, E. Scoccimarro, A. Navarra, M. Dacic, SINTA Simulations of climate change in the Mediterranean Area, Instituto Nazionale di Geofisica e Vulcanologia (INGV), 2008.

[14] UBFF (University of Belgrade Faculty of Forestry), Hydrological-hydrolics Study on causes of floods in municipality Krupanj in May 2014, Belgrade, 2014.

[15] S. Milanović, Unapređenje sistema za zaštitu šuma od požara u Republici Srbiji, Ministarstvo 
poljoprivrede, šumarstva i vodoprivrede - Uprava za šume, Beograd, 2017. https://upravazasume.gov.rs/wp-content/uploads/2018/03/KONACNI-IZVESTAJ-POZARI-MILANOVIC.pdf

[16] Д. Караџић, С. Милановић, В. Голубовић Ћургуз, Узроичи сушења смрче (Picea abies Karst.) на подручју парка природе „Голија“, Шумарски факултет Универзитета у Београду, Београд, 2017.

[17] S. Milanović, Lj. Mihajlović, D. Karadžić, L. Jankovsky, P. Aleksic, M. Janković-Tomanić, J. Lazarević, Effects of pedunculate oak tree vitality on gypsy moth preference and performance, Archives of Biological Sciences, 66 (2014), pp. 1659-1672. https://doi.org/10.2298/ABS1404659M

[18] R. Ristić, A. Marković, B. Radić, Z. Nikić, N. Vasiljević, N. Živković, S. Dragićević, Environmental Impacts in Serbian Ski Resorts, Carpathian Journal of Earth and Environmental Sciences, 6, 2 (2011), pp. 125-134.

[19] V. Kapos, Effects of isolation on the water status of forest patches in the Brazilian Amazon, Journal of Tropical Ecology, 5 (1989), pp. 173-185.

[20] R. Ristić, M. Kašanin-Grubin, B. Radić, Z. Nikić, N. Vasiljević, Land degradation in ski resort "Stara planina", Environmental Management, 49, pp. 580592.

[21] Institute for Nature Protection of Serbia, Red book of threatened species, Ministry of Environment Protection and University of Belgrade, Faculy of Biology, Belgrade, 1999.

[22] R. Ristić, B. Radić, Z. Nikić, N. Vasiljević, Environmental Impact Assessment - Ski run Sunčana dolina - Stara planina, Faculty of Forestry, Belgrade, 2008.

[23] A. Nemeth, B. Mesquita, C. Monnier, J. Pecalevska, Illegal Logging in South Eastern Europe, Regional Action Plan, REC Working Paper, The Regional Environmental Center for Central and Eastern Europe (REC), Szentandre, Hungary, 2012.

[24] Savcor Indufor Oy, Ensuring sustainability in forestry through improved management and control of illegal logging in transitional countries - Study for Serbia, Helsinki, Finland, 2009.

[25] M. Jovanovic, M. Milanovic, Remote Sensing and Forest Conservation: Challenges of Illegal Logging in Kuršumlija Municipality (Serbia), Forest Ecology and Conservation, 4 (2017), pp. 99-118.

[26] http://www.elektrosrbija.rs/me/images/dokumenti/ Katastar\%20MHE\%20u\%20Srbiji.pdf

[27] IWRMJČ (Institute for Water Resources Management „Jaroslav Černi“), Water Resources Management Basic Plan of Serbia (WRMBPS), Ministry of Agriculture, Forestry and Water Resources Management, Belgrade, 2001.
[28] World Bank Group,Environmental, Health, and Safety Approaches for Hydropower Projects, International Finance Corporation, Washington D.C., 2018.

[29] R. Ristić, I. Malušević, S. Polovina, V. Milčanović, B. Radić, Small Hydropower Plants - Derivation Type: Insignificant Energy benefit and Immeasurable Environmental Damage, Vodoprivreda, 50, 294-296 (2018), pp. 311-317.

[30] U. Eichelmann, A. Scharl, Remove the Dams-Free our Rivers (Concept Paper), RiverWatch, Manfred Hermsen Stiftung, Vienna, Austria, 2017.

[31] BGEN (Balkan Green Energy News), StudyEuropean financed small hydropower plants damaging pristine Balkan, 2017. (https://balkangreenenergynews.com/study-european-financed-smallhydropower-plants-damaging-pristine-balkan/).

[32] I. Vejnović, P. Gallop, Financing for Hydropower in protected areas in Southeast Europe: 2018 update, Euronatur, Riverwatch, supported by Manfred - Hermsen - Stiftung, 2018

[33] A. Neslen, Balkan hydropower projects soar by $300 \%$ putting wildlife at risk, research shows, The Guardian, November, 2017. (https://www.theguardian.com/environment/2017/nov/27/balkan-hydropower-projects-soar-by-300-putting-wildlife-atrisk-research-shows).

[34] R. Ristić, S. Kostadinov, V. Milčanović, B. Radić, I. Malušević, Torrential Floods, spatial and urbanistic planning in Serbia, VIII International Conference on Spatial Planning and Environmental Protection, Palić, Serbia, 2015, Proceedings, pp. 507-513.

[35] R. Ristić, S. Kostadinov, B. Abolmasov, S. Dragićević, G. Trivan, B. Radić, M. Trifunović, Z. Radosavljević, Torrential floods and town and country planning in Serbia, Natural Hazards and Earth System Sciences, 1, 12 (2012), pp. 23-35.

[36] Lj. Jevtić, Engineering Handbook for Torrent and Erosion Control, University of Belgrade Faculty of Forestry, Yugoslavia, Belgrade, 1978.

[37] R. Ristić, G. Macan, The Impact of erosion control measures on runoff Processes, Red Book - IAHS Publ., England, 1997, pp. 191-194.

[38] R. Ristić, G. Macan, Investigation of interception in beech-fir stand on mountain Goč. Journal of the Faculty of Forestry, 86, (2002), pp.181-188.

[39] R. Ristić, S. Kostadinov, D. Malošević, V. Spalević, Erosion aspect in estimation of hydrologic soil group and determination of runoff curve number CN, Soil and Plant, 50 (3) (2001), pp.165-174.

[40] F. I. Nondedeu, F. Rey, A. Bedecarrats, Contributions of vegetation cover and cattle hoof prints towards seed runoff control on ski pistes, Ecological Engineering, 27 (2006), pp.193-201. 
[41] J. A. Jones, D. A. Post, Seasonal and successional streamflow response to forest cutting and regrowth in the northwest and eastern United States, Water Resources Research, 40 (2004), p.19.
[42] C. A. Troendle, W. K. Olsen, Potential effects of timber harvest and water management on stream flow dynamics and sediment transport, USDA Forest Service, General Technical Report, 247 (1994), pp. 34-41.

\title{
УЛОГАТА НА ШУМСКИТЕ ЕКОСИСТЕМИ ВО ПРОЦЕСОТ НА УБЛАЖУВАЊЕ И АДАПТАЦИЈА КОН ЕФЕКТИТЕ НА КЛИМАТСКИТЕ ПРОМЕНИ
}

\author{
Ратко Ристиќ*, Иван Малушевиќ, Борис Радиќ, Слободан Милановиќ, \\ Вукашин Милчановиќ, Синиша Половина
}

${ }^{1}$ Шумарски факултет, Универзитет во Белград, Србија

\begin{abstract}
Шумските екосистеми обезбедуваат широк ранг на екосистемски услуги и имаат важна улога во одржувањето на животот на планетата Земја. Климатските промени во Североисточна Европа и прогнозите за периодот до 2070 година имаат големо влијание врз сегашните и идните планирања во управувањето со шумите и со водите поради забележаните трендови: зголемување на средногодишната температура на воздухот за 2,5$5,0^{\circ} \mathrm{C}$ до крајот на 21 век; редистрибуција на годишните врнежи, со многу повеќе врнежи во периодот пролетлето, преку краткотрајни и интензивни врнежи; намалување на годишните врнежи и на влажноста на почвите за 10-20\%, со екстремни последици, како што се сушење и исчезнување на шумите во ридско-планинските региони. Деградацијата и губењето на шумите води кон зголемување и интензивирање на ерозијата на почвите, со зачестени буични поплави, калишта, лизгања на земјиштето и лавини. Стабилните шумски екосистеми се столбови на одржливиот развој и на репопулацијата, и може да обезбедат средства и ресурси за справување и за надминување на сиромаштијата во планинските подрачја на Југоисточна Европа.
\end{abstract} планирање

Клучни зборови: шумски екосистеми; климатски промени; заштита од поплави; контрола на ерозија, 